TAPROBANICA, ISSN 1800-427X. April, 2012. Vol. 04, No. 01: pp. 48-51.

(C) Taprobanica Private Limited, Jl. Kuricang 18 Gd.9 No.47, Ciputat 15412, Tangerang, Indonesia.

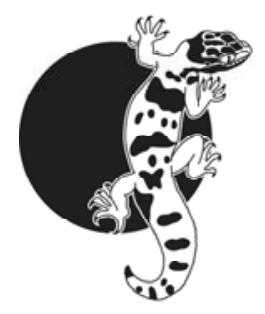

\section{Xenopeltis unicolor Boie, 1827 predation upon Sphenomorphus sp.}

Xenopeltis is a genus of non-venomous snakes characterized by its iridescent, highly polished scales which give to the species the common name "sunbeam snake". Currently, two species are recognized (Bergman, 1955; McDiarmid et al., 1999; Rooij, 1917). Xenopeltis unicolor Boie, 1827 is found in Southeast Asia and some regions of Indonesia occupying a variety of habitats from primary to secondary forests, agricultural and settled areas from elevations up to $1402 \mathrm{~m}$ (Bergman, 1955; Das, 2010; McDiarmid et al., 1999; Rooij, 1917). Being nocturnal and subfossorial, this species inhabits burrows excavated by small mammals and crevices within limestones, spending large amounts of time underground on the leaf litter (Das, 2010; McDiarmid et al., 1999). Pre-maxillary teeth are found in the aglyphous dentition of $X$. unicolor (Dowling, 1959) enabling a varied diet that consists primarily of frogs, lizards (particularly skinks), small mammals (such as rodents), birds and even other snakes (Bergman, 1955; Das, 2010; McDiarmid et al., 1999; Rooij, 1917).

Mertens (1943) described a first predation event in a captive specimen. The author recorded a predation upon a frog being eaten within few seconds. This snake used to be fed every week on a frog, lizard or mouse. In general, the prey was firmed right away being killed by suffocation, or sometimes as much as half an hour later. The frog was then swallowed quickly afterward.

Despite being the most frequently traded species in some areas of Southeast Asia (such as U Minh Thuong National Park, Viet Nam) (Stuart, 2004), its ecology and natural history is still largely unknown (Das, 2004a). Approximately 130 species are currently assigned to the speciose genus Sphenomorphus of which 16 can be found in Borneo Island (Das, 2004b; Greer \& Shea, 2004; Grismer, 2007). Species of this large group are known to inhabit deep in forests, avoiding sun flecks. However, individuals can climb several meters up tree trunks to avoid predators or even some can seek safety in riparian microhabitats (Inger, 1959; Malkmus, 1991; Inger et al., 2001). Montane species tend to be more secretive in their habits which leave them poorly understood (Grismer, 2007). Sympatry is common, particularly in some areas of Borneo, where many species present overlapping distribution (Inger et al., 2001).

In this manuscript we describe a predation event by an individual of Xenopeltis unicolor upon a Sphenomorphus species occurring at the Danum Valley. This report represents a more detailed item in this snake's species diet in the wild as well as a new confirmed predator for these Bornean skinks.

During research work carried out in Borneo Island, on 28 October 2009, an adult individual of $X$. unicolor $(\mathrm{TL} \pm 70 \mathrm{~cm})$, reddish brown dorsum with white cream ventre, was observed preying on Sphenomorphus sp. The predation episode was recorded at the Danum Valley Field Center (at $4^{\circ} 58^{\prime}$ N, $118^{\circ} 48^{\prime} \mathrm{E}, 200 \mathrm{~m}$ a.s.l.) located on the eastern border of the Danum Valley Conservation Area on the east coast of the Malaysian state of Sabah, Borneo Island. Danum Valley Conservation Area is the largest remaining area of undisturbed lowland (<760m) evergreen forest, where dipterocarps consist of up to $80 \%$ of the canopy trees (Marsh \& Greer, 1992; Newbery et al. 1992). The climate at Danum is equatorial with a mean annual temperature of $26.7^{\circ} \mathrm{C}$ and mean relative humidity between 78\% and 95\% (Marsh \& Greer, 1992; Walsh, 1990).

When the team approached the spot (at 10h16am, temp. $28^{\circ} \mathrm{C}$ and humidity $80 \%$ ), the Xenopeltis unicolor individual was hidden under a rotten log on the leaf litter, near a small stream. The skink was then observed a few seconds later getting closer to the crevice where the snake was lying, without noticing its presence. Suddenly, there was an ambush with the snake appearing under the rubble of the trunk and firmly seizing its prey by the head 
(at 10:20 hr). The Sphenomorphus sp. was immediately immobilized by a double wrap of the snake's body while being secured by the enlarged maxillary teeth deeply embedded into the back of its head. In a closer view of the scene, it became visible that the skink was still alive, moving and struggling in an attempt to escape, for about 30 seconds, while the snake was biting and suffocating it. The Xenopeltis maintained its firm grasp for about 1 minute after capture, tightly restricting the skink with its body. It started swallowing its prey from the head. As reported by Savitzky (1983), the teeth are flexibly mounted on the jaws to permit their hinging or rotation while swallowing (fig. 1.AC) and so it took about 3 minutes until the tip of the skink tail was completely inside the snake's mouth (at 10h25am). The behavior reported (killing and swallowing) lasted for about 5 minutes. After the predation, the snake returned to the gravel of the rotten log where it remained in its refuge (fig. 1.D).
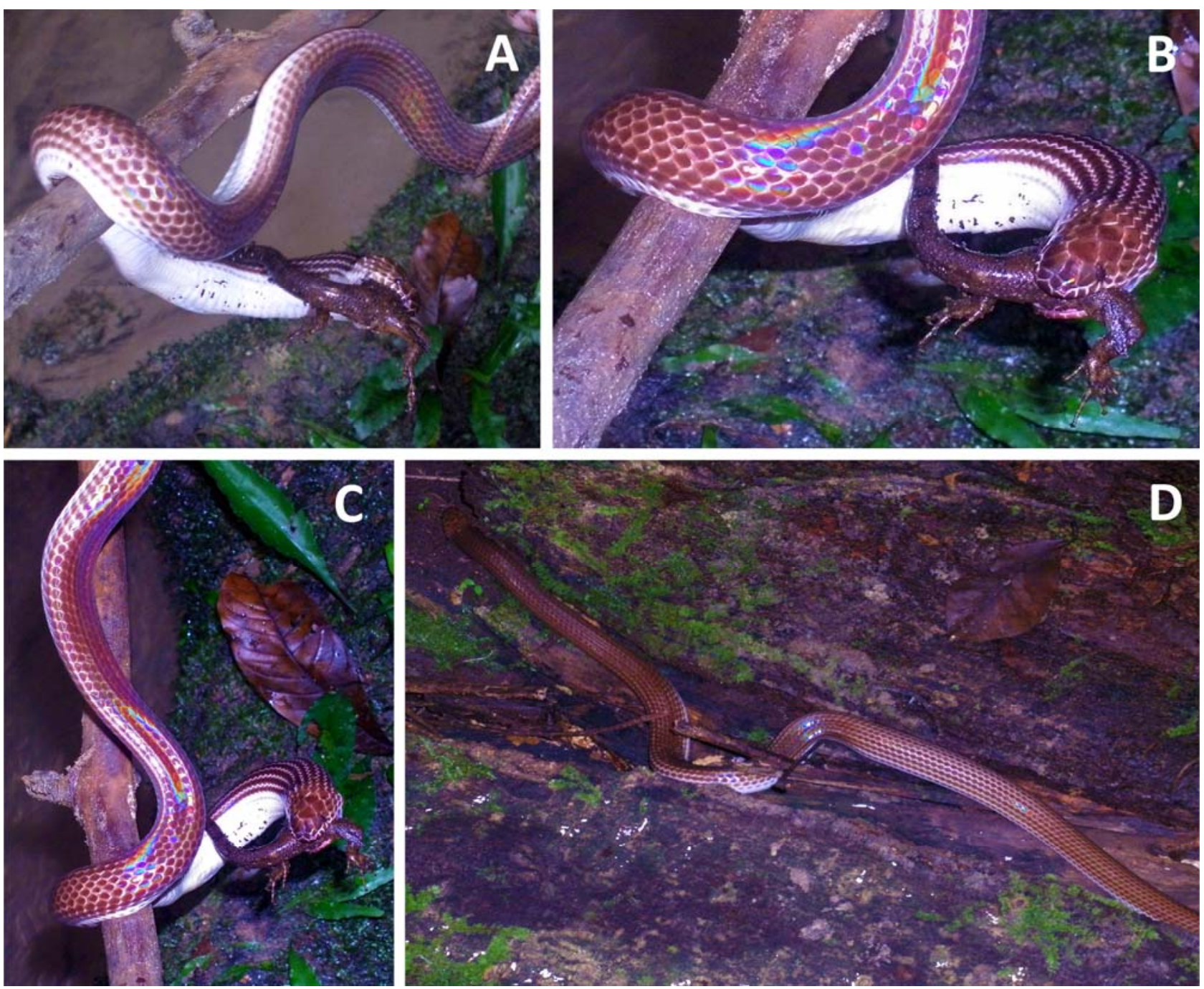

Figure 1: Xenopeltis unicolor predating upon a Sphenomorphus sp. (A) Snake seizing and immobilising the skink; (B \& C) snake swallowing its prey, starting from the head; (D) snake searching for its refugee under the log after eating the skink. (Photos: B. H. Martins)

Taxonomic identification of Sphenomorphus group is very difficult (Greer \& Shea, 2004) and, during our observation, it was not possible to note the critical diagnostic characters in order to be certain on the species. At the Danum Valley three Sphenomorphus species have been recorded: $S$. hallieri, S. multisquamatus and S. sabanus (Inger et al., 2001). However, we believe that the snake doesn't restrict its diet to a single species, especially when these skink species are so similar to one another in habits and in general form (e.g., Inger et al., 2001).

Despite the increased research development in the Southeast Asia and the fact that perhaps the Danum Valley Field Centre is the leading forest research 
station in tropical Asia (e.g. Fayle et al., 2010; Inger et al., 2001; O'Malley, 2009), there is still the need for continuous studies for greater knowledge and to better understand this important ecosystem. In addition, over the last years, the continuous new discoveries of amphibians and reptiles indicates that the knowledge about the herpetofauna in Borneo is still scarce and therefore much remains to be learned in order to develop consistent conservation strategies (Das, 2004a; Grismer, 2007).

\section{Acknowledgements}

This observation was made during a Tropical Biology Association field course supported by the BAT Biodiversity Partnership Borneo Programme. The authors thank to the Royal Society South East Asian Rainforest Research Program and other staff of Danum Valley Field Centre for the support. Robert F. Inger for his valuable comments and insights on the species identification, M. M. Bahir and Christopher Durrant for reviewing the manuscript; finally to Lucília Tibério, Richard Gibson and Ivan Rehak..

\section{Literature cited}

Bergman, R. A. M., 1955. The anatomy of Xenopeltis unicolor. Zoologische Mededelingen, 33 (22): 209225.

Das, I., 2004a. Collecting in the "land below the wind", herpetological explorations of Borneo. Bonner zoologische Beiträge, 52 (3-4): 231-243.

Das , I. 2004b. Lizards of Borneo. Natural History Publications, Kota Kinabalu, Borneo: 83.

Das, I., 2010. A field guide to the reptiles of Southeast Asia. New Holland Publishers, Ltd. London: 376.

Dowling, H. G., 1959. Classification of the Serpentes. a critical review. Copeia, 1959 (1): 38-52.

Fayle, T. M., L. Bakker, C. Cheah, T. M. Ching, A. Davey, F. Dem, A. Earl, Y. Huaimei, S. Hyland, B. Johansson, E. Ligtermoet, R. Lim, L. K. Lin, P. Luangyotha, B. H. Martins, A. F. Palmeirim, S. Paninhuan, S. K. Rojas, L. Sam, P. T. T. Sam, D. Susanto, A. Wahyudi, J. Walsh, S. Weigl, P. G. Craze, R. Jehle, D. Metcalfe and R. Trevelyan, 2010. A positive relationship between ant biodiversity (Hymenoptera: Formicidae) of scavenger-mediated nutrient redistribution along a disturbance gradient in a south-east Asian rain forest. Myrmecological News, 14: 5-12.
Greer, A. E. and G. Shea, 2004. A new character within the taxonomically difficult Sphenomorphus group of lygosomine skinks, with a description of a new species from New Guinea. Journal of Herpetology, 38: 79-87.

Grismer, L. L., 2007. A new species of small montane forest floor skink (Genus Sphenomorphus Fitzinger 1843) from southern peninsular Malaysia. Herpetologica, 63 (4): 544-551.

Inger, R. F., 1959. Temperature responses and ecological relations of two Bornean lizards. Ecology, 40 (1): 127-136.

Inger, R. F., T. F. Lian, M. Lakim and P. Yambun, 2001. New species of the lizard genus Sphenomorphus, (Lacertilia: Scincidae), with notes on ecological and geographic distribution of species in Sabah, Malaysia. The Raffles Bulletin of Zoology, 49 (2): 181-189.

Malkmus, R., 1991. Sphenomorphus aquaticus sp. n. (Sauria: Scincidae) vom Mount Kinabalu/NordBorneo. Sauria, 13: 23-28.

Marsh, C. W. and A. G. Greer, 1992. Forest land-use in Sabah, Malaysia: An introduction to Danum Valley. Philosophical Transactions of the Royal Society of London, Series B, 335(1275): 331-339.

Mertens, R., 1943. Systematische und ökologische Bemerkungen über die Regenbogenschlange, Xenopeltis unicolor Reinwardt. Der Zoologische Garten (N.F.), 15: 213-220.

McDiarmid, R. W., J. A. Campbell and T. Touré, 1999. Snake species of the World: a taxonomic and geographic reference, vol. 1. Herpetologists' League. Washington: 511.

Newbery, D. McC., E. J. F. Campbell, Y. F. Lee, C. E. Ridsdale and M. J. Still, 1992. Primary lowland dipterocarp forest at Danum Valley, Sabah, Malaysia: structure, relative abundance and family composition. Philosophical Transactions of the Royal Society of London, Series B, 335 (1275): 341-356.

O'Malley, K., 2009. Patterns of abundance and diversity in epiphytic orchids on Parashorea malaanonan trees in Danum Valley, Sabah. The Plymouth Student Scientist, 2 (2): 38-58.

Rooij, N. D., 1917. The reptiles of the Indo-Australian archipelago, vol. II. Ophidia. Leiden: E.J. Brill, Holland: 334. 
Savitzky, A. H., 1983. Coadapted character complexe among snakes: fossoriality, piscivory, durophagy. American Zoologist, 23 (2): 397-409.

Stuart, B. L., 2004. The harvest and trade of reptiles at U Minh Thuong National Park, southern Viet Nam. TRAFFIC Bulletin, 20 (1): 25-34.

Walsh, R. P. D., 1990. Climatic data for Danum Valley. Unpublished Danum Valley Field Centre Report No. 98. Sabah, East Malaysia:

Submitted: 11 April 2012, Accepted: 13 April 2012 Sectional Editor: Gernot Vogel

Bruno H. Martins ${ }^{1}$ \& Gonçalo M. Rosa ${ }^{2,3}$

${ }^{1}$ CIBIO - Centro de Investigação em Biodiversidade e Recursos Genéticos, Porto, Portugal

${ }^{2}$ Durrell Institute of Conservation and Ecology, School of Anthropology and Conservation, University of Kent, Canterbury, Kent, CT2 7NR, UK

${ }^{3}$ Centro de Biologia Ambiental, Faculdade de Ciências da Universidade de Lisboa, Bloco C2, Campo Grande, 1749-016 Lisboa, Portugal

E-mail: goncalo.m.rosa@gmail.com 